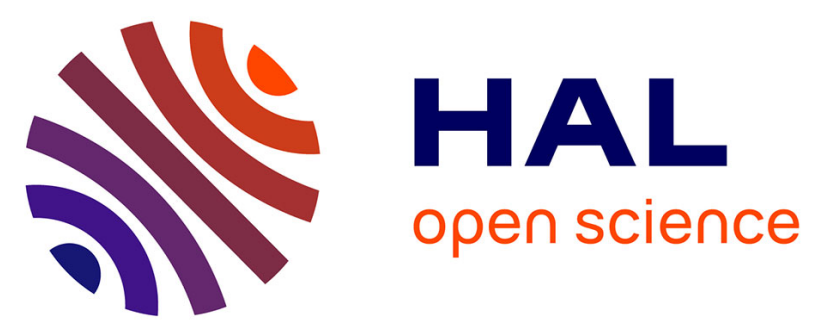

\title{
Identification and quantification of phytoprostanes and phytofurans of coffee and cocoa by- and co-products
}

Bani Mariana Ruesgas-Ramón, Maria-Cruz Figueroa-Espinoza, Erwann

Durand, Mirna L. Suárez-Quiroz, Oscar González-Ríos, Amandine Rocher, Guillaume Reversat, Joseph Vercauteren, Camille Oger, Jean-Marie Galano, et al.

\section{To cite this version:}

Bani Mariana Ruesgas-Ramón, Maria-Cruz Figueroa-Espinoza, Erwann Durand, Mirna L. SuárezQuiroz, Oscar González-Ríos, et al.. Identification and quantification of phytoprostanes and phytofurans of coffee and cocoa by- and co-products. Food and Function, 2019, 10 (10), pp.6882-6891. 10.1039/C9FO01528K . hal-02330239

\section{HAL Id: hal-02330239 https://hal.science/hal-02330239}

Submitted on 18 Dec 2019

HAL is a multi-disciplinary open access archive for the deposit and dissemination of scientific research documents, whether they are published or not. The documents may come from teaching and research institutions in France or abroad, or from public or private research centers.
L'archive ouverte pluridisciplinaire HAL, est destinée au dépôt et à la diffusion de documents scientifiques de niveau recherche, publiés ou non, émanant des établissements d'enseignement et de recherche français ou étrangers, des laboratoires publics ou privés. 


\title{
Identification and quantification of phytoprostanes and phytofurans of coffee and cocoa by- and co-products $\dagger$
}

\author{
Mariana Ruesgas-Ramón, ${ }^{a}$ Maria Cruz Figueroa-Espinoza, (D) *a \\ Erwann Durand, (D) a,b Mirna L. Suárez-Quiroz, (D) C Oscar González-Ríos, (D) c \\ Amandine Rocher, ${ }^{d}$ Guillaume Reversat, ${ }^{d}$ Joseph Vercauteren, (D) d \\ Camille Oger, (D) d Jean-Marie Galano, ${ }^{d}$ Thierry Durand (D) ${ }^{d}$ and Claire Vigor (DD *d
}

\begin{abstract}
Phytoprostanes (PhytoPs) and phytofurans (PhytoFs) are isoprostanoids that result from the peroxidation of $\alpha$-linolenic acid and are biomarkers of oxidative stress in plants and humans. These compounds exhibit several interesting biological activities (e.g. neuroprotection and anti-inflammatory activities). The aim of this research was to add value to coffee pulp (CP), cocoa husk (CH) and cocoa pod husk (CPH) by identi-fying and quantifying PhytoPs and PhytoFs by liquid chromatography-tandem mass spectrometry. The contents of PhytoPs and PhytoFs in CP, CH, and CPH were, respectively, 654.6, 474.3 and 179.9, and 543.2, 278.0 and 393.8 ng per g dry weight (dw). The main PhytoP found in CP (171.37 ng per $\mathrm{g} \mathrm{dw}$ ) and $\mathrm{CPH}$ (37.12 ng per g dw) was 9-epi-9- $\mathrm{F}_{1 \mathrm{t}}$-PhytoP, while ent-9- $\mathrm{L}_{1 \mathrm{t}}$-PhytoP was the most abundant in $\mathrm{CH}$ (109.78 $\mathrm{ng}$ per $\mathrm{g} \mathrm{dw}$ ). The main PhytoF found in all sources was ent-16(RS)-13-epi-ST- $\Delta^{14}$-9-PhytoF, at 196.56, 126.22, and 207.57 $\mathrm{ng}$ per $\mathrm{g}$ $\mathrm{dw}$ in $\mathrm{CP}, \mathrm{CH}$, and $\mathrm{CPH}$, respectively. We provide the first complete profile of PhytoPs and PhytoFs for these agro-residues, which could be used in the functional food indus-try for enriching food or as nutritional supplements.
\end{abstract}

\section{Introduction}

Coffee is one of the most widely traded agricultural commodities and the most frequently consumed beverages in the world. ${ }^{1}$ Chocolate and other derived products are widely distributed and consumed around the world (e.g. milk chocolate drinks, solid bars of chocolate, cookies, cakes, and candies). ${ }^{2}$ Both products are the most important agro-tropical crops; in 2016, the world production of green coffee and cocoa reached 9.22 and 4.47 million tons, respectively. ${ }^{3}$

Most Arabica green coffee beans (Coffea arabica L.) in the world are obtained through the coffee wet process. In this process, the damaged and unripe berries are first eliminated by flotation, and then the outer skin and most of the pulp of

${ }^{a}$ IATE, Univ Montpellier, CIRAD, INRA, Montpellier SupAgro, Montpellier, France. E-mail: maria.figueroa@supagro.fr

${ }^{b}$ CIRAD, UMR IATE, F-34398 Montpellier, France

${ }^{c}$ Tecnológico Nacional de México/Instituto Tecnológico de Veracruz. UNIDA, Miguel Ángel de Quevedo $N^{\circ} 2779,91860$ Veracruz, Veracruz, Mexico

${ }^{d}$ Institut des Biomolécules Max Mousseron, IBMM, University of Montpellier, CNRS, ENSCM, Faculty of Pharmacy, Montpellier, France.

E-mail: claire.vigor@umontpellier.fr the sunken fruits are mechanically removed by pressing the fruit in water using a pulper. The obtained beans are fermented to remove the layer of pulp remnants and the mucilage layer. After $12-48 \mathrm{~h}$ of fermentation, the beans are washed and dried to about $12 \%$ moisture content and de-hulled to remove the parchment (Fig. 1). The resulting solid wastes (parchment and silverskin) are collectively termed parchment husks. On average, for every one ton of clean coffee produced, 0.28 tons of parchment husk and 0.5 tons of pulp would be generated. ${ }^{4}$ The main coffee waste is thus the pulp (CP) which represents $40 \%$ of the fresh weight of coffee cherries. ${ }^{5}$

In the case of cocoa processing significant quantities of side products, mostly cocoa pod husk $(\mathrm{CPH})$ and cocoa husk $(\mathrm{CH})$, are produced. ${ }^{6} \mathrm{CPH}$ is immediately discarded after the cocoa's harvest and represents $74 \%$ of the cocoa fruit weight. ${ }^{7}$ After fermentation, drying, and roasting, $\mathrm{CH}$ is removed from the cocoa beans, and then the nibs are used for the production of chocolate (Fig. 1). $\mathrm{CH}$ represents between $12 \%$ and $20 \%$ of the total weight of the dry cocoa bean. ${ }^{8}$

Due to the great demand for green coffee and cocoa beans, large amounts of residues are generated after processing in both producing and processing countries, and if badly managed they present a serious disposal problem. For instance, when they are left on the fields, they can lead to 


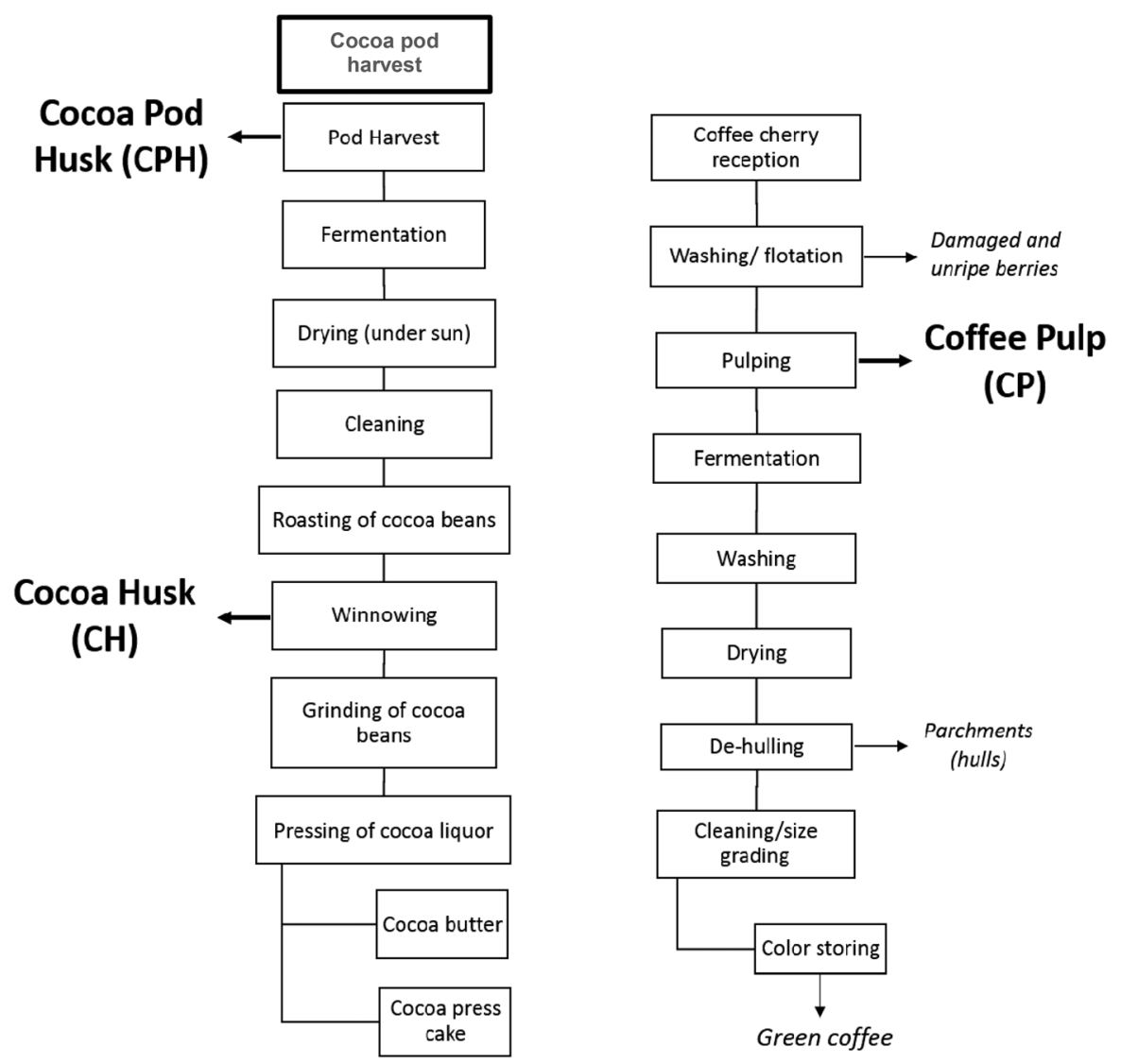

Fig. 1 Diagram of green coffee wet processing (adapted from ref. 40) and cocoa processing (adapted from ref. 8).

environmental problems, creating bad odors, and causing mold diseases and landscape deterioration. ${ }^{9}$

Mexico ranked eleventh and thirteenth in the worldwide production of green coffee (151714 ton) and cocoa beans (26836 ton), respectively, in 2016. ${ }^{10}$ Considering this, in 2016, the coffee industry generated around 159.9 thousand tons of waste (including hulls, skin mucilage, and pulp). ${ }^{11}$ In the case of cocoa, the generation of agricultural waste is estimated to be 241.3 thousand tons including cocoa husk and cocoa pod husk. $^{8,12}$

To face this situation, several studies have been proposed with the aim of adding value to these derived co- and by-products, while decreasing their negative environmental impact. These residues are an interesting and cheap renewable source of biomolecules (carbohydrates such as cellulose, hemicellulose, and pectin, proteins, lipids, and bioactive phytonutrients like polyphenols, pigments, etc.), which can be used in the formulation of food and non-food products as they exhibit interesting physicochemical and/or biological activities (e.g. surface active agents, gelifying agents, antioxidants, ${ }^{13,14}$ and antimicrobials). ${ }^{15}$ However, as far as we know, to date, no report has considered coffee and cocoa by- and co-products as a potential source of phytoprostanes (PhytoPs) and phytofurans (PhytoFs).

Isoprostanes (IsoPs) and isofurans (IsoFs) are the products of free radical-induced peroxidation of polyunsaturated fatty acids (PUFAs), such as arachidonic acid, in animal cells. Similarly, in plants, isoprostanoids such as PhytoPs and PhytoFs are formed by non-enzymatic oxidation of $\alpha$-linolenic acid (C18:3 n-3, ALA). ${ }^{16}$ The absorption of such molecules by the human body can be through food intake or pollen aspiration. ${ }^{17}$ These lipid mediators are likely to play a role in the development of the brain and central nervous system, could also be involved in the prevention of metabolic disorders, ${ }^{18}$ seem to present cytoprotective responses in immature brain cells such as neuroblasts and oligodendrocytes, ${ }^{19}$ or could act as mediators of oxidative stress. ${ }^{20}$ In addition, they could be involved in anti-inflammatory and apoptosis-inducing activities. $^{21}$ Consequently, there is growing interest in studying the molecular profile and amount of these kinds of compounds in plant foods and their response to cultural and postharvest transformation practices and/or environmental conditions. These compounds have been found in an array of medicinal plants, and natural or unprocessed and processed plant foods, such as cereals, nuts and oilseeds, macroalgae, some fruits and legumes (for a review of the occurrence of these compounds see ref. 22 and 23). Recently, León-Perez et al. ${ }^{22}$ reported the presence of PhytoPs and PhytoFs in dry fermented cocoa beans, but as far as we know, no reports exist on the content of these molecules either in coffee or in cocoa by- and co-products. Hence, the interest of this work that aims at the identification and quantification of PhytoPs and PhytoFs from 
coffee pulp (CP), cocoa husk $(\mathrm{CH})$ and cocoa pod husk $(\mathrm{CPH})$ is to add value to these agro-residues from the coffee and cocoa industry. Indeed, PhytoP and PhytoF rich extracts could be obtained from these agro-residues to enrich food or to be used as nutritional supplements due to their interesting biological activities.

\section{Materials and methods}

\section{Biological material}

CP (from Coffea arabica var. sachimor) was collected in March in Huatusco (Veracruz, Mexico), while $\mathrm{CH}$ and $\mathrm{CPH}$ (from Theobroma cacao L. Criollo) were collected in June in Comalcalco (Tabasco, Mexico), both in 2016. CH was obtained as a by-product of the conventional industrial roasting process from the collection center of AMCO Company located in Tabasco, Veracruz, Mexico. CP and $\mathrm{CPH}$ were chopped and dried in a fluidized bed dryer (GRACO, TGA101) in lots of $3 \mathrm{~kg}$, for $90 \mathrm{~min}$ at $60{ }^{\circ} \mathrm{C}$. The dried raw material was milled in a kitchen-type grinder (Moulinex Deluxe Stainless Steel Mill 843, France), sieved to particle sizes between 315 and $630 \mu \mathrm{m}$, and then stored at $-20{ }^{\circ} \mathrm{C}$ before experiments.

\section{Materials}

The internal standards (IS) d4-15- $\mathrm{F}_{2 \mathrm{t}}$-IsoPs were purchased from Cayman Chemical (Ann Arbor, MI, USA). The internal standards C19-16- $\mathrm{F}_{1 \mathrm{t}}$-PhytoPs, and the external standards ent-

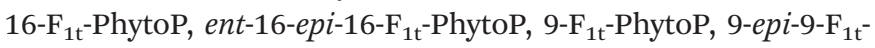

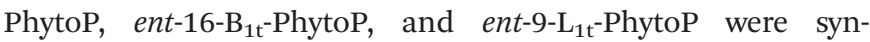
thesized according to the previously described procedure. The PhytoP stock solutions were prepared in methanol at a concentration of $100 \mathrm{ng} \mu \mathrm{L}^{-1}$ and stored at $-20^{\circ} \mathrm{C}$.

LC-MS methanol, acetonitrile, and HPLC chloroform were purchased from Fisher Scientific (Loughborough, UK). Hexane, formic acid, acetic acid, absolute ethanol, ammonia, and potassium hydroxide $(\mathrm{KOH})$ were obtained from SigmaAldrich (Saint-Quentin-Fallavier, France). Ethyl acetate (HPLC grade) and butylated hydroxytoluene (BHT) were supplied by VWR (EC) and Acros Organics (Geel, Belgium), respectively. The water used in this study was purified on a MilliQ system (Millipore) or provided by Fisher Scientific (Loughborough, UK). SPE Oasis MAX 3cc cartridges (60 mg) were obtained from Waters (Milford, MA, USA).

\section{Extraction of Isoprostanoids}

PhytoP and PhytoF extraction was performed in triplicate with approximately $0.1 \mathrm{~g}$ of each sample. The plant material was mixed with $2 \mathrm{~mL}$ of $\mathrm{MeOH}$ containing $1 \%(\mathrm{v} / \mathrm{v})$ of butylated hydroxytoluene (BHT). Then, the mixture was vortexed and $1.5 \mathrm{~mL}$ of phosphate buffer $(\mathrm{pH} 2)$ saturated in $\mathrm{NaCl}$, and $6 \mathrm{ng}$ of each IS were added. This solution was stirred for $1 \mathrm{~h}$ at $100 \mathrm{rpm}$ at room temperature. Then, the extract was centrifuged at $4000 \mathrm{rpm}$ for $5 \mathrm{~min}$ at $25^{\circ} \mathrm{C}$, the supernatant was separated, and $4 \mathrm{~mL}$ of cold chloroform were added. This mixture was vortexed for $30 \mathrm{~s}$ and then centrifuged at $1500 \mathrm{rpm}$ for
$5 \mathrm{~min}$ at room temperature. Subsequently, the chloroform phase was separated and concentrated under a nitrogen flow at $40{ }^{\circ} \mathrm{C}$ for $2 \mathrm{~h}$. Afterward, $950 \mu \mathrm{L}$ of $\mathrm{KOH}$ were added, the mixture was incubated for $30 \mathrm{~min}$ at $40^{\circ} \mathrm{C}$, and $1 \mathrm{~mL}$ of formic acid (40 mM, pH 4.6) was added before running the SPE separation. SPE Oasis MAX cartridges were conditioned with $2 \mathrm{~mL}$ of $\mathrm{MeOH}$ and equilibrated with $2 \mathrm{~mL}$ of formic acid $(20 \mathrm{mM}, \mathrm{pH}$ 4.5). After loading the sample, the cartridges were successively washed with: $2 \mathrm{~mL}$ of $\mathrm{NH}_{3} 2 \%(\mathrm{v} / \mathrm{v}), 2 \mathrm{~mL}$ of a mixture of formic acid $(20 \mathrm{mM}): \mathrm{MeOH}(70: 30, \mathrm{v} / \mathrm{v}), 2 \mathrm{~mL}$ of hexane, and finally $2 \mathrm{~mL}$ of hexane : ethyl acetate $(70: 30, \mathrm{v} / \mathrm{v})$. The targeted metabolites were eluted with $2 \mathrm{~mL}$ of a hexane: ethanol:acetic acid mixture $(70: 29.4: 0.6, \mathrm{v} / \mathrm{v})$. Lastly, all samples were evaporated to dryness under a nitrogen flow at $40{ }^{\circ} \mathrm{C}$ for $30 \mathrm{~min}$, and $100 \mu \mathrm{L}$ of $\mathrm{H}_{2} \mathrm{O}: \mathrm{ACN}(0.1 \%$ (v/v) formic acid) (83:17, v/v) were added prior to injection into the micro-HPLC-QTRAP system.

\section{Identification and quantification of isoprostanoids}

PhytoPs and PhytoFs, extracted from $\mathrm{CP}, \mathrm{CH}$, and $\mathrm{CPH}$, were chromatographied using a micro-LC equipped with CTC Analytics AG (Zwingen, Switzerland), as described by Yonny et $a .^{24}$ The autosampler vial tray was kept at $10{ }^{\circ} \mathrm{C}$ and the column (HALO C18 $0.5 \times 100 \mathrm{~mm}, 2.7 \mu \mathrm{m}$, Eksigent Technologies, CA, USA) was set at $40{ }^{\circ} \mathrm{C}$. The mobile phase consisted of water with $0.1 \%(\mathrm{v} / \mathrm{v})$ formic acid (A) and acetonitrile : methanol $(80: 20, \mathrm{v} / \mathrm{v}$; with $0.1 \%(\mathrm{v} / \mathrm{v})$ of formic acid) (B). The gradient elution program was performed as follows ( $\mathrm{min} / \% \mathrm{~B}): 0 / 17 ; 1.6 / 17 ; 2.85 / 21 ; 7.3 / 25 ; 8.8 / 28.5$; $11 / 33.3 ; 15 / 40 ; 16.5 / 95 ; 18.9 / 95 ; 19 / 17 ; 21 / 17$.

$5 \mu \mathrm{L}$ of the sample was injected and eluted at a flow rate of $0.03 \mathrm{~mL} \mathrm{~min}^{-1}$. An AB SCIEX QTRAP 5500 mass spectrometer (Sciex Applied Biosystems) was used to analyze isoprostanoids. The ionization source was an electrospray (ESI), operated in the negative mode. The source voltage was maintained at $-4.5 \mathrm{kV}$ and nitrogen was used as the curtain gas. Multiple reaction monitoring (MRM) of each compound was performed, allowing the determination of two transitions, one for quantification (T1), the other for specification (T2) (Table 1). The analysis was conducted by monitoring the precursor ion to product ion (T1) transition. Peak detection, integration and quantitative analysis were performed using MultiQuant 3.0 software (Sciex Applied Biosystems).

Isoprostanoid quantification was based on the calibration curves obtained from the ratio of analyte to IS area under the curve. Linear regression of 6 concentration levels of the PhytoP and PhytoF mixture $\left(16,32,64,128,256\right.$ and $\left.512 \mathrm{pg} \mu \mathrm{L}^{-1}\right)$ of each analyte is presented in Table 2 . The sensitivity of the method is evaluated through LOD and LOQ parameters which were defined as the lowest concentration with a signal to noise ratio above 3 and 10 respectively. According to the type of isoprostanoids, LOD and LOQ range from 0.16 to $0.63 \mathrm{pg}$ injected and 0.16 to $1.25 \mathrm{pg}$ injected, respectively.

In order to validate the methodology, the extraction yield (EY) and matrix effect (ME) were evaluated in order to assess the efficiency of sample processing. These parameters, specific to each compound (external standards and IS), allow the evalu- 
Table 1 PhytoP and PhytoF quantification by micro-LC-MS/MS

\begin{tabular}{|c|c|c|c|}
\hline Compounds & $\begin{array}{l}\text { Calibration } \\
\text { curve }\end{array}$ & $R^{2}$ & Weighting \\
\hline ent-16- $\mathrm{F}_{1 \mathrm{t}}-\mathrm{PhytoP}$ & $y=1.06857 x$ & 0.997 & $1 / x$ \\
\hline ent-16-epi-16- $\mathrm{F}_{1 \mathrm{t}}$-PhytoP & $y=0.87312 x$ & 0.998 & $1 / x$ \\
\hline $9-\mathrm{F}_{1 \mathrm{t}}-$ PhytoP & $y=0.79830 x$ & 0.998 & $1 / x$ \\
\hline 9-epi-9-F ${ }_{1 \mathrm{t}}-\mathrm{PhytoP}$ & $y=0.71005 x$ & 0.998 & $1 / x$ \\
\hline ent-16- $\mathrm{B}_{1 \mathrm{t}}$-PhytoP & $y=1.92920 x$ & 0.991 & $1 / x$ \\
\hline ent-9- $\mathrm{L}_{1 \mathrm{t}}-\mathrm{Phyto}$ & $y=2.87653 x$ & 0.983 & $1 / x$ \\
\hline ent-16(RS)-9-epi-ST- $\Delta^{14}-10$-PhytoF & $y=1.71852 x$ & 0.998 & $1 / x$ \\
\hline ent-9(RS)-12-epi-ST- $\Delta^{10}$-13-PhytoF & $y=0.72222 x$ & 0.998 & $1 / x$ \\
\hline ent-16(RS)-13-epi-ST- $\Delta^{14}$-9-PhytoF & $y=1.95197 x$ & 0.997 & $1 / x$ \\
\hline
\end{tabular}

${ }^{a}$ Six data points $(n=3) ; y$ : the peak area of the analyte; $x$ : the concentration of the analyte $\left(\mathrm{pg} \mu \mathrm{L}^{-1}\right)$. The deuterated form of IsoPs $\left(\mathrm{D}_{4}{ }^{-}\right.$ $15 \mathrm{~F}_{2 \mathrm{t}}$-IsoP) and $\mathrm{C} 19-16-\mathrm{F}_{1 \mathrm{t}}$-PhytoP were used as internal standards for quantification of samples in this study.

Table 2 Multiple reaction monitoring (MRM) of PhytoPs and PhytoFs

\begin{tabular}{|c|c|c|c|}
\hline Compounds & $R_{\mathrm{t}}(\min )$ & $\begin{array}{l}\text { Precursor } \\
\text { ions }(m / z)\end{array}$ & $\begin{array}{l}\text { Product } \\
\text { ions }(\mathrm{m} / \mathrm{z})\end{array}$ \\
\hline Ent-16-B 1 -PhytoP_T1 & 10.50 & 307.2 & 235 \\
\hline Ent-16-B ${ }_{1 \mathrm{t}}$-PhytoP_T2 & 10.50 & 307.2 & 223 \\
\hline 9/16-F 1 t-PhytoP_T1 & $5.58-6.27$ & 327.2 & 283.2 \\
\hline 9-F $1 \mathrm{t}-$ PhytoP_T2 & 5.75 & 327.2 & 171.2 \\
\hline 9-epi-9- $\mathrm{F}_{1 \mathrm{t}}-\mathrm{PhytoP} \_\mathrm{T} 2$ & 6.27 & 327.2 & 171.2 \\
\hline $16-\mathrm{F}_{1 \mathrm{t}}-\mathrm{PhytoP} \_\mathrm{T} 2$ & 6.04 & 327.2 & 251.2 \\
\hline 16-epi-16- $\mathrm{F}_{1 \mathrm{t}}$-PhytoP_T2 & 5.58 & 327.2 & 251.2 \\
\hline Ent-9-L ${ }_{1 \mathrm{t}}-\mathrm{PhytoP} \_\mathrm{T} 1$ & 10.67 & 307.2 & 185.1 \\
\hline 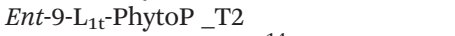 & 10.67 & 307.2 & 197 \\
\hline Ent-16(RS)-13-epi-ST- $\Delta^{14}$-9-PhytoF_T1 & 4.68 & 343.2 & 201 \\
\hline Ent-16(RS)-13-epi-ST- $\Delta^{14}$-9-PhytoF_T2 & 4.68 & 343.2 & 127 \\
\hline Ent-16(RS)-9-epi-ST- $\Delta^{14}-10$-PhytoF_T1 & 4.68 & 343.2 & 209.1 \\
\hline Ent-16(RS)-9-epi-ST- $\Delta^{14}-10$-PhytoF_T2 & 4.68 & 343.2 & 199 \\
\hline Ent-9(RS)-12-epi-ST- $\Delta^{10}-13-P h y t o F_{-} \mathrm{T} 1$ & 4.56 & 343.2 & 237.1 \\
\hline Ent-9(RS)-12-epi-ST- $\Delta^{10}-13-P h y t o F_{-} \mathrm{T} 2$ & 4.56 & 343.2 & 86.9 \\
\hline
\end{tabular}

ation of product losses due to the extractive process or a skew in the mass quantification due to ion suppression or an increase caused by the sample matrix and interference from metabolites. The experiments described below were performed in triplicate for each plant material ( $\mathrm{CP}, \mathrm{CH}$, and $\mathrm{CPH})$. The EY is calculated by comparing the area under the peak observed for a sample spiked by a known concentration of metabolites at the end of the extractive process $\left(A_{\text {After }}\right)$ and the area for an equivalent sample spiked at the beginning of the extractive process $\left(A_{\text {Before }}\right)$. The results, expressed in percentage ( $\mathrm{EY}=A_{\mathrm{Before}} / A_{\mathrm{After}} \times$ 100), are given for two concentrations of standards (32 and $256 \mathrm{pg} \mu \mathrm{L}^{-1}$ of compounds with IS). The ME is calculated by comparing the area under the peak observed for a sample spiked by a known concentration of metabolites at the end of the extractive process $\left(A_{\mathrm{After}}\right)$ and the area under the peak observed for pure standards in the mobile phase at the same concentration $\left(A_{\text {Pure }}\right)$. The calculation is: $\mathrm{ME}=A_{\text {After }} / A_{\text {Pure }} \times 100$.

\section{Fatty acid identification and quantification}

The CP, CH, and CPH lipid determination was performed by Soxhlet extraction using chloroform as a solvent according to the AOAC method. ${ }^{41}$ Afterward, the extracts were converted into methyl esters (FAMEs) according to the NF T60-233 method. ${ }^{42}$ The fatty acid profile was determined on a GC Agilent 6890 (Bios Analytique, France) series, equipped with an INNOWax capillary column (SGE, Courtaboeuf, France), with the following characteristics: length, $30 \mathrm{~m}$; internal diameter, $0.32 \mathrm{~mm}$, and film thickness, $0.25 \mathrm{~mm}$. Helium was used as the carrier gas with a flow of $1 \mathrm{~mL} \mathrm{~min}^{-1}$ and a splitting ratio of 1/80 was used. The temperature of the injector was $250{ }^{\circ} \mathrm{C}$ and the flame ionization detector was set at $270{ }^{\circ} \mathrm{C}$. The oven was heated from $185^{\circ} \mathrm{C}$ to $225^{\circ} \mathrm{C}$ at $5^{\circ} \mathrm{C} \min ^{-1}$ and maintained at $225^{\circ} \mathrm{C}$ for 20 min. FAMEs were identified by comparison with commercially available standards (Sigma-Aldrich, France). The ALA content was expressed as mg per $\mathrm{g} d w$ of each plant material, according to the relative amount $(\% \mathrm{w} / \mathrm{w})$ of this fatty acid in the lipid fraction.

\section{Statistical analysis}

Statistical analysis (one-way analysis of variance ANOVA) was performed using Minitab software version 18 (Minitab Inc., USA). The level of significance was set at $p<0.05$. The results are expressed as the mean of triplicates (mean values \pm standard deviations). Tukey's test was used to determine which mean values were different.

\section{Results and discussion}

PhytoPs and PhytoFs are produced by non-enzymatic oxidation of ALA which are primary metabolites commonly found in the plant membranes. Thus, it would not be surprising to identify such molecules in coffee and cocoa by- or co-products. The identification and quantification assays were performed on Mexican coffee pulp (CP), cocoa husk (CH), and cocoa pod husk (CPH).

The recovery of PhytoPs and PhytoFs can be influenced by several factors, such as the efficiency of separation during the liquid/liquid extraction step, the affinity of compounds for the selected phases or the selectivity of the used SPE cartridges. ${ }^{25}$ In addition, the possible PhytoP and PhytoF co-elution with the compound(s) present in the raw $\mathrm{CP}, \mathrm{CH}$, and $\mathrm{CPH}$ materials may affect the ionization during LC-MS/MS analysis, therefore leading to an inaccuracy in measurements. ${ }^{26}$ Thus, taking into account these crucial factors, EY and ME parameters are determined. These data allow us to better define the method and deduce by calculation a value closer to reality of metabolite rates present in the raw material. In this study, we observed an excellent recovery rate for each matrix, notably for PhytoFs of CP with the EY ranging from 95 to $97 \%$ (Table 3). In this matrix, the PhytoPs' EY varies between 71 and $96 \%$. In the case of $\mathrm{CH}$, the EYs were observed to range from 72 to $97 \%$ and 76 to $86 \%$ for PhytoPs and PhytoFs, respectively. Finally, for $\mathrm{CPH}$, the values are between 95 and $111 \%$ for PhytoPs and 88 and $96 \%$ for PhytoFs. The EY of a few metabolites reaching more than $100 \%$ may correspond to the co-elution of a compound that presents the same MRM transition. 
Table 3 Percentage of matrix effect and extraction yield of isoprostanoid derivatives

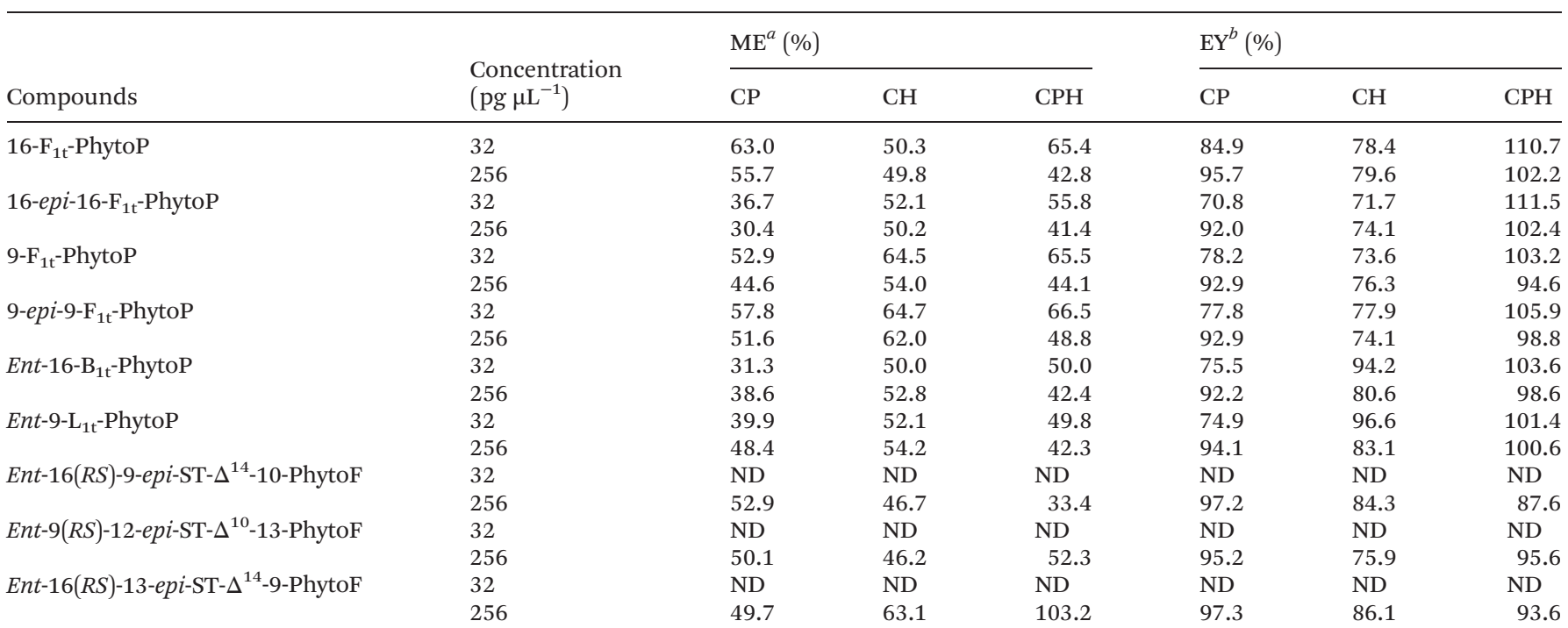

${ }^{a}$ Matrix effect (\%) measured by micro-LC-MS/MS for coffee pulp (CP), cocoa husk (CH), and cocoa pod husk (CPH). ${ }^{b}$ Extraction yield (\%) measured by micro-LC-MS/MS for coffee pulp (CP), cocoa husk (CH), and cocoa pod husk (CPH). ND: not determined.

In this study, an important matrix effect $(\mathrm{CP}, \mathrm{CH}$, and $\mathrm{CPH})$ on the isoprostanoid estimation was observed (Table 3), either by decreasing (for PhytoPs) or by increasing (for PhytoFs) the content of the analyzed compounds. For instance, the matrix effect for different PhytoPs ranged from $30.4 \%$ to $63 \%, 49.8 \%$ to $64.7 \%$, and $41.4 \%$ to $66.5 \%$, in $\mathrm{CP}, \mathrm{CH}$, and $\mathrm{CPH}$, respectively, whereas it ranged from $49.7 \%$ to $52.9 \%, 46.2 \%$ to $63.1 \%$, and $33.4 \%$ to $103.2 \%$, in $\mathrm{CP}, \mathrm{CH}$, and $\mathrm{CPH}$, respectively, for PhytoFs (Table 3). Thus, one may say that the quantity of PhytoPs is actually underestimated with respect to the actual quantity in the starting materials, whereas it is likely overestimated for PhytoFs.

\section{Analysis of phytoprostanes in $\mathrm{CP}, \mathrm{CH}$, and $\mathrm{CPH}$}

$\mathrm{CP}$, which is obtained after depulping during coffee processing (Fig. 1), has the highest PhytoP concentration. In traditional primary green coffee wet processing, CP undergoes natural fermentation, as it is left overnight at ambient temperature before being treated or discarded. To avoid uncontrolled fermentation, which could influence the PhytoP concentration, the CP used in this study was immediately dried after the depulping step. The total PhytoP content in CP was $654.6 \mathrm{ng}$ per $\mathrm{g}$ dw, 9-epi-9- $\mathrm{F}_{1 \mathrm{t}^{-}}$ PhytoP (171.4 ng per g dw) and 9- $\mathrm{F}_{1 \mathrm{t}}$-PhytoP (145.6 ng per $\mathrm{g} \mathrm{dw}$ ) being the major-quantified PhytoPs (Table 4, ESI $\dagger$ ). These two compounds have already been reported in cocoa beans ${ }^{22}$ and as olive oil biomarkers of water stress in olive trees, as their content in extra virgin olive oil correlated with water deficiency in olive tree plantations. ${ }^{27}$ Similarly, an important variation of 9- $\mathrm{F}_{1 \mathrm{t}}$-PhytoP was identified in melon leaves when the plant was exposed to thermal stress. ${ }^{24}$ In our case, the presence of these PhytoPs was not dependent on the hydric stress in coffee trees, as coffee was harvested in a region located $1300 \mathrm{~m}$ above the

Table 4 Qualitative and quantitative profile of isoprostanoids in coffee pulp (CP), cocoa husk (CH), and cocoa pod husk (CPH)

\begin{tabular}{|c|c|c|c|}
\hline \multirow[b]{2}{*}{ Compounds } & \multicolumn{3}{|c|}{ Isoprostanoid concentration $^{a}$ (ng per $\mathrm{g} \mathrm{dw}$ ) } \\
\hline & $\mathrm{CP}$ & $\mathrm{CH}$ & $\mathrm{CPH}$ \\
\hline Ent-16- $\mathrm{F}_{1 \mathrm{t}}-\mathrm{PhytoP}$ & $123.4 \pm 3.1^{\mathrm{a}}$ & $41.2 \pm 2.7^{\mathrm{a}}$ & $19.0 \pm 1.6^{\mathrm{a}}$ \\
\hline 16-epi-16- $\mathrm{F}_{1 \mathrm{t}}$-PhytoP & $86.8 \pm 2.5^{\mathrm{b}}$ & $39.6 \pm 2.6^{\mathrm{a}}$ & $20.2 \pm 1.6^{\mathrm{a}}$ \\
\hline 9- $\mathrm{F}_{1 \mathrm{t}}$-PhytoP & $145.6 \pm 6.2^{\mathrm{c}}$ & $76.5 \pm 3.0^{\mathrm{b}, \mathrm{c}}$ & $37.0 \pm 0.8^{\mathrm{b}}$ \\
\hline 9-epi-9- $\mathrm{F}_{1 \mathrm{t}}-$ PhytoP & $171.4 \pm 4.8^{\mathrm{d}}$ & $67.7 \pm 1.4^{\mathrm{c}}$ & $37.1 \pm 1.1^{\mathrm{b}}$ \\
\hline Ent-16- $\mathrm{B}_{1 \mathrm{t}}$-PhytoP & $60.7 \pm 2.2^{\mathrm{e}}$ & $110.5 \pm 9.5^{\mathrm{b}}$ & $34.0 \pm 4.0^{\mathrm{b}}$ \\
\hline Ent-9- $\mathrm{L}_{1 \mathrm{t}}$-PhytoP & $66.7 \pm 3.0^{\mathrm{e}}$ & $138.8 \pm 12.5^{\mathrm{d}}$ & $32.6 \pm 3.3^{\mathrm{b}}$ \\
\hline Ent-16(RS)-9-epi-ST- $\Delta^{14}-10$-PhytoF & $163.2 \pm 5.8^{\mathrm{f}}$ & $62.8 \pm 5.6^{\mathrm{f}}$ & $43.5 \pm 1.2^{\mathrm{f}}$ \\
\hline Ent-9(RS)-12-epi-ST- $\Delta^{10}-13$-PhytoF & $183.4 \pm 7.1^{\mathrm{g}}$ & $89 \pm 0.7^{g}$ & $142.7 \pm 8.9^{g}$ \\
\hline Ent-16(RS)-13-epi-ST- $\Delta^{14}-9$-PhytoF & $196.6 \pm 0.6^{\mathrm{g}}$ & $126.2 \pm 6.6^{\mathrm{h}}$ & $207.6 \pm 11.7^{\mathrm{h}}$ \\
\hline
\end{tabular}

\footnotetext{
${ }^{a}$ Expressed as dry weight and quantified by micro-LC-MS/MS. The results are the mean of triplicates (mean values \pm standard deviations measured according to Pearson (divided by $n$ ), values followed by the same letter are not significantly different in Tukey's test using $95 \%$ confidence level). Coffee pulp (CP), cocoa husk (CH), and cocoa pod husk (CPH).
} 
sea level, with an average annual temperature and rainfall of $19.1{ }^{\circ} \mathrm{C}$ and $1825 \mathrm{~mm}$, respectively, ${ }^{28}$ corresponding to good Arabica growing conditions. Indeed, according to Chapagain and Hoekstra, the water requirement of a coffee plant is about $1277 \mathrm{~mm}$ per year. ${ }^{29}$ Thus, the PhytoP amounts extracted from $\mathrm{CP}$ could be considered as base values under the optimal climate conditions for growing Arabica coffee trees. Monitoring the PhytoP concentration in plants grown under hydric and/or thermal stress could allow the determination of the relationship between the PhytoP content and these factors. Hence, this information could also be used as biomarkers of hydric and/or thermal stress in coffee trees, as previously demonstrated for olive trees and melon leaves.
On the other hand, it would also be interesting to investigate how different edaphoclimatic conditions influence the qualitative and quantitative profile of PhytoPs and PhytoFs in the coffee plant and each by- and co-product.

Regarding cocoa products, the total content of PhytoPs in $\mathrm{CH}$ and $\mathrm{CPH}$ was, respectively, 474.3 and $179.9 \mathrm{ng}$ per $\mathrm{g} \mathrm{dw}$ (Table 4, ESI $\dagger$ ). Post-harvest processing could partially explain this value, since $\mathrm{CH}$ was obtained after the fermentation and roasting steps (Fig. 1). The main compound found in $\mathrm{CH}$ was ent-9- $\mathrm{L}_{1 \mathrm{t}}$-PhytoP (138.8 ng per $\mathrm{g} \mathrm{dw}$ ), followed by ent-16- $\mathrm{B}_{1 \mathrm{t}}{ }^{-}$ PhytoP (110.5 ng per $\mathrm{g} \mathrm{dw}$ ) and $9-\mathrm{F}_{1 \mathrm{t}}$-PhytoP (76.5 ng per $\mathrm{g}$ $\mathrm{dw})$. In comparison, in cocoa beans, the most abundant PhytoP is $9-\mathrm{F}_{1 \mathrm{t}}$-PhytoP (114.52-1134.08 $\left.\mathrm{ng} \mathrm{g}^{-1}\right) .^{22}$ These com-

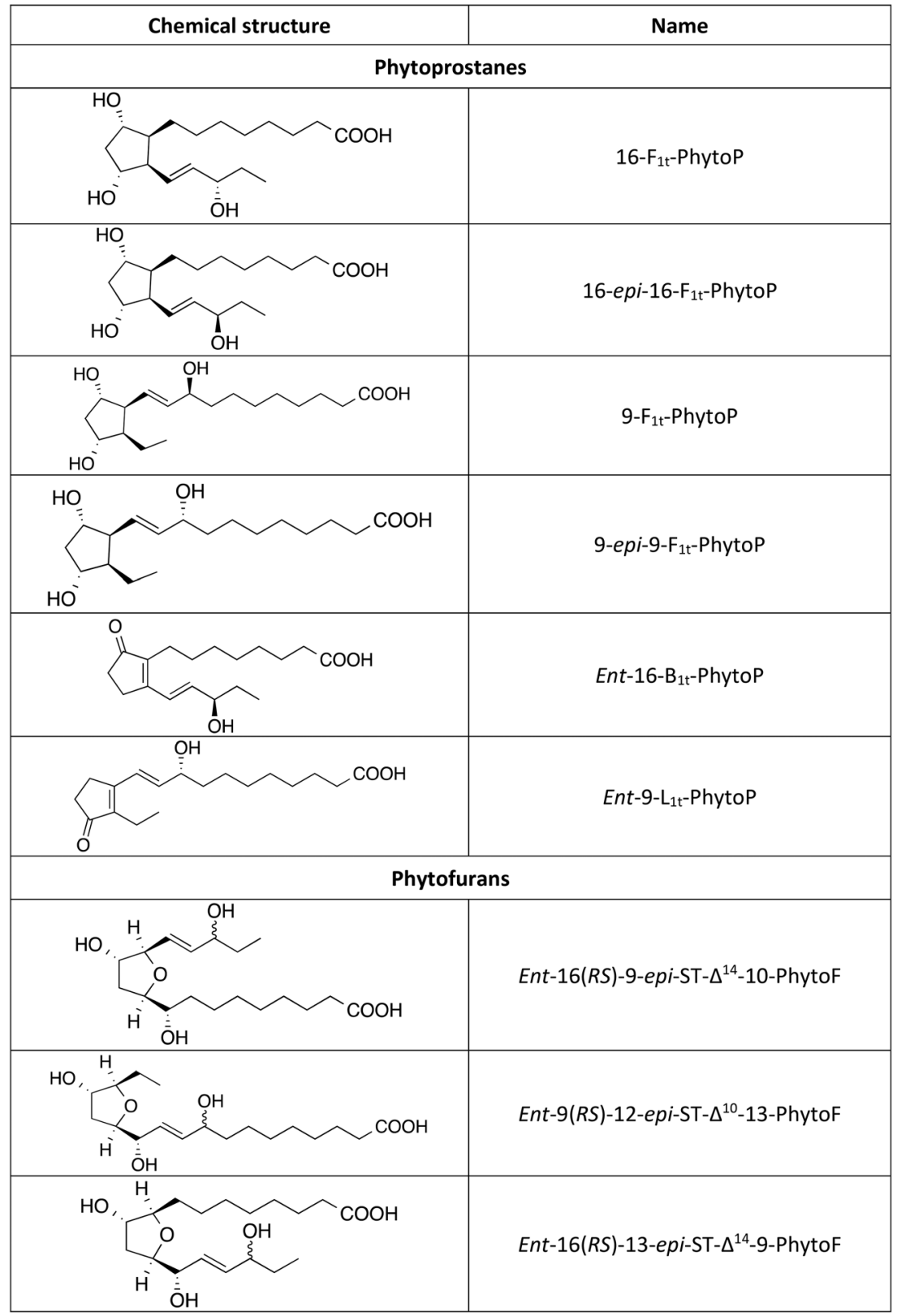

Fig. 2 Chemical structures of phytoprostanes and phytofurans present in coffee pulp (CP), cocoa husk (CH), and cocoa pod husk (CPH). 
pounds have already been identified in different rice flours. ${ }^{30}$ The $9-\mathrm{L}_{1 \mathrm{t}}$-PhytoP series has been reported in melon leaves, ${ }^{24}$ extra virgin olive oil, ${ }^{27}$ walnut, macadamia nuts, and pecan nuts as minor components. ${ }^{17}$ In addition, it was observed that frying at $130{ }^{\circ} \mathrm{C}$ increased the concentration of these compounds in macadamia nuts by 2.3 -fold. ${ }^{17}$

9- $\mathrm{F}_{1 \mathrm{t}}$-PhytoP and 9-epi-9- $\mathrm{F}_{1 \mathrm{t}}$-PhytoP ( $\sim 37 \mathrm{ng}$ per $\left.\mathrm{g} \mathrm{dw}\right)$, ent-

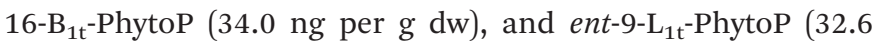
$\mathrm{ng}$ per $\mathrm{g} \mathrm{dw}$ ) were the main compounds extracted from $\mathrm{CPH}$. The stereoisomer $9-\mathrm{F}_{1 \mathrm{t}}$-PhytoP was found in CP (145.6 ng per $\mathrm{g} \mathrm{dw}$ ) and $\mathrm{CPH}(37.0 \mathrm{ng}$ per $\mathrm{g} \mathrm{dw})$. The $9-\mathrm{F}_{1 \mathrm{t}}$-PhytoP serie was predominant in kernel nuts, up to $7.8 \mathrm{ng} \mathrm{g}^{-1} \cdot{ }^{17}$ In olive trees, hydric stress has been shown to increase the content of certain $\mathrm{F}_{1 \mathrm{t}^{-}}$and $\mathrm{B}_{1 \mathrm{t}}$-PhytoPs. Accordingly, the authors pro-

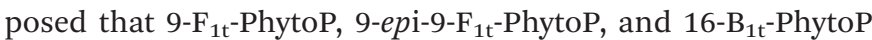
+ ent-16- $\mathrm{B}_{1 \mathrm{t}}$-PhytoP could be considered as early biomarkers of water stress. ${ }^{27}$ On the other hand, the $\mathrm{B}_{1 \mathrm{t}}$-PhytoP series has been found in high levels in linseed oil, ${ }^{31}$ and is likely involved in the regulation of gene expression in Arabidopsis thaliana and tobacco. ${ }^{32}$

Several vegetable matrices have been characterized by their total PhytoP content. The retrieved concentrations of PhytoPs in $\mathrm{CP}, \mathrm{CH}$ and $\mathrm{CPH}$ suggest that they are valuable sources of these compounds. Our results are consistent with

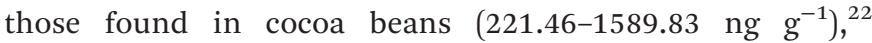
brown macroalgae (Ectocarpus siliculosus) (310 $\left.\mathrm{ng} \mathrm{g}^{-1}\right),{ }^{39}$ and leaves, flowers and roots of different plants (43-1380 $\left.\mathrm{ng} \mathrm{g}^{-1}\right),{ }^{16}$ and they are similar to or higher than those found in almonds (40.25-238.09 $\left.\mathrm{ng} \mathrm{g}^{-1}\right),{ }^{33}$ musts (21.4-447.1 $\left.\mathrm{ng} \mathrm{g}^{-1}\right),{ }^{34}$ rice bran $\left(22.20-118.00 \mathrm{ng}^{-1}\right)$ and white and brown rice flours (2.55-32.89 $\left.\mathrm{ng} \mathrm{g}^{-1}\right){ }^{33}$ Passiflora edulis Sims shell (1.3-67.6 $\left.\mathrm{ng} \mathrm{g}^{-1}\right),{ }^{35}$ and raw green table olive fruits (5.81-9.99 $\left.\mathrm{ng} \mathrm{g}^{-1}\right) .{ }^{36}$ Dry leaves of melon plants subjected or not subjected to thermal stress (2620-3210 and 4620-6280 $\mathrm{ng} \mathrm{g}^{-1}$, respectively), ${ }^{24}$ fertigated French beans (Phaseolus vulgaris) (22 $641 \mathrm{ng} \mathrm{g}^{-1}$ ), pea (132 $755 \mathrm{ng} \mathrm{g}^{-1}$ ), and "mangetout" (Pisum sativum spp. arvense) (263134 $\left.\mathrm{ng} \mathrm{g}^{-1}\right)^{37}$ are the ones with the highest total PhytoP concentration found in the literature. More recently, León-Perez et $a l^{22}$ reported a total PhytoP and PhytoF content ranging from 221.46 to $1589.83 \mathrm{ng} \mathrm{g}^{-1}$ and from 1.18 to $13.13 \mathrm{ng} \mathrm{g}^{-1}$, respectively, in dry fermented cocoa beans.

In our study, $\mathrm{CP}$ was the material with the highest content of PhytoPs (654.6 ng per $\mathrm{g} \mathrm{dw}$ ). This result could be ascribed to the ALA concentration since CP has the highest content of ALA (160.7 mg per $\mathrm{g} d w$ ), in comparison with $\mathrm{CPH}$ and $\mathrm{CH}$ (82.8 and $52.1 \mathrm{mg}$ per $\mathrm{g} \mathrm{dw}$, respectively) (Fig. 3). Moreover, $\mathrm{CPH}$ showed the lowest PhytoP concentration (181.2 ng per $\mathrm{g} \mathrm{dw}$ ), likely because this by-product did not undergo further processing steps, except a moderate drying before being stored (Fig. 3).

In conclusion, considering the isoprostanoids' interest (biological activities among others), the total amount of PhytoPs in $\mathrm{CP}, \mathrm{CH}$, and $\mathrm{CPH}$ (ranging from 179.9 to $654.6 \mathrm{ng} \mathrm{g}^{-1}$ ) is very interesting and could confer new applications for these unexploited agro-residues.

\section{Phytofurane analysis in $\mathrm{CP}, \mathrm{CH}$, and $\mathrm{CPH}$}

Three different PhytoFs were characterized in our samples (Table 4, Fig. 2). Similar to PhytoPs, these molecules are produced by non-enzymatic oxidation of PUFAs via a parallel pathway after the initial endoperoxide formation and further oxygenation is required. ${ }^{38}$

Ent-16(RS)-9-epi-ST- $\Delta^{14}$-10-PhytoF, ent-9(RS)-12-epi-ST- $\Delta^{10}$ 13-PhytoF, and ent-16(RS)-13-epi-ST- $\Delta^{14}$-9-PhytoF were identified in $\mathrm{CP}, \mathrm{CH}$, and $\mathrm{CPH}$. As shown in Table 4, the total PhytoF content in ng per $\mathrm{g}$ dw was: $543.2(\mathrm{CP}), 278.0(\mathrm{CH})$, and $393.8(\mathrm{CPH})$, showing that these by- and co-products are

a)
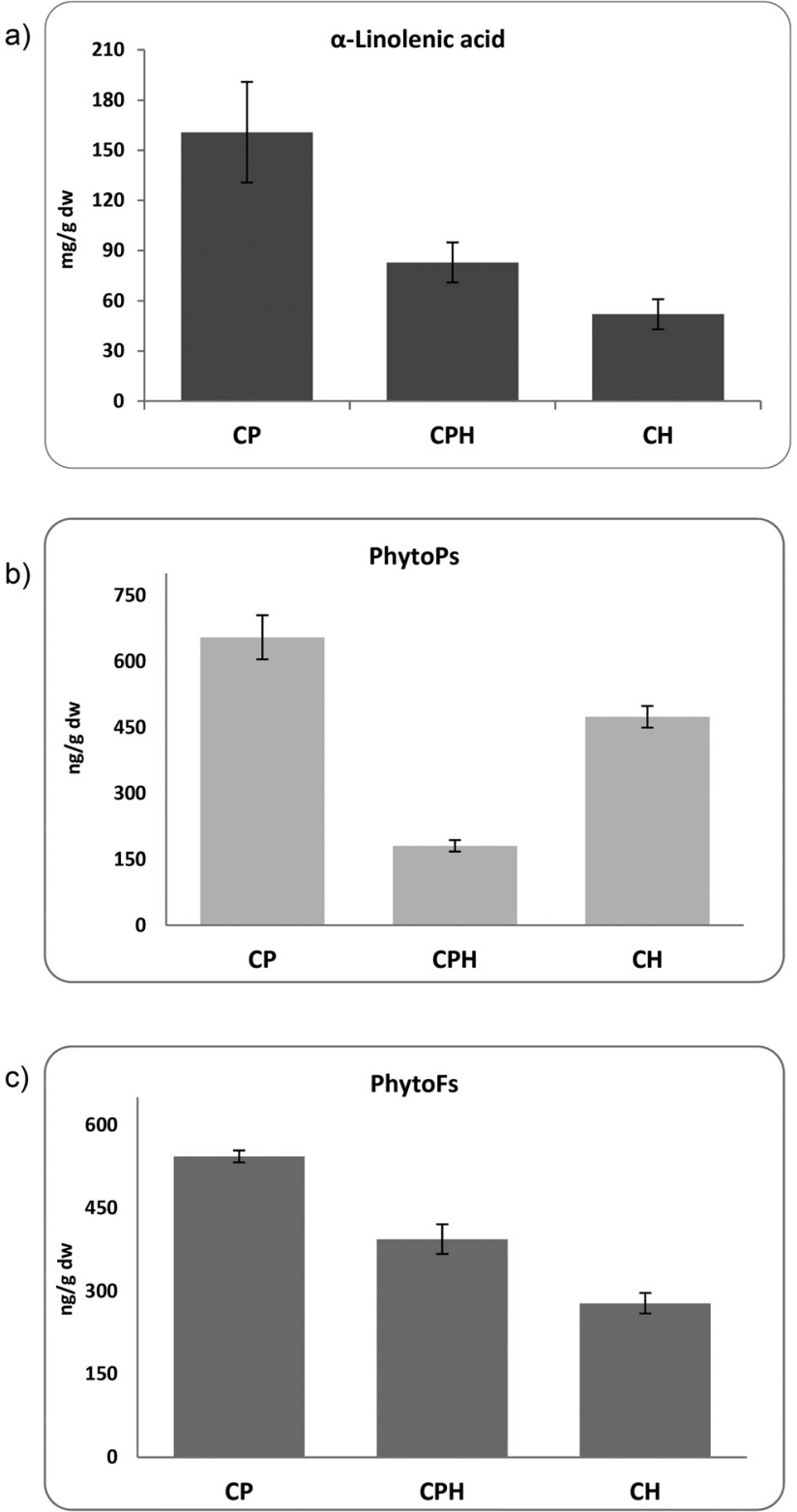

Fig. 3 Comparison between the concentrations of $\alpha$-linolenic acid, phytoprostanes (PhytoPs) and phytofurans (PhytoFs) in coffee pulp (CP), cocoa husk $(\mathrm{CH})$ and cocoa pod husk $(\mathrm{CPH})$. The values of each column are the mean of triplicates (mean values \pm standard deviations). 
an interesting source of PhytoFs. These values are higher than the ones found in, e.g. dry fermented cocoa beans (1.18 to $\left.13.13 \mathrm{ng} \mathrm{g}^{-1}\right)^{22}$ and white and brown rice flours and rice bran $\left(0.69,4.2\right.$, and $10.3 \mathrm{ng}$ per $\mathrm{g} \mathrm{dw}$, on an average, respectively), ${ }^{30}$ and similar to those reported in brown macroalgae (Ectocarpus siliculosus) (486 $\left.\mathrm{ng} \mathrm{g}^{-1}\right),{ }^{39}$ but lower than those found in pea (Pisum sativum var. BGE-033620) (4258 $\left.\mathrm{ng} \mathrm{g}^{-1}\right)^{37}$ and dry leaves of melon plants subjected or not subjected to thermal stress (1960-2750 and 3250-4810 $\mathrm{ng} \mathrm{g}^{-1}$, respectively). ${ }^{24}$ The epimeric mixture of ent-16(RS)-13-epi-ST- $\Delta^{14}$-9-PhytoF predominates in the three samples. These compounds were identified and quantified for the first time in different nuts and seeds in concentrations up to 10 and $16.06 \mathrm{ng} \mathrm{g}^{-1}$ in walnut ${ }^{18}$ and brown rice flour, ${ }^{30}$ respectively. The second main compound extracted from CP (183.4 ng per $\mathrm{g} \mathrm{dw}$ ), $\mathrm{CH}$ (89.0 ng per $\mathrm{g} \mathrm{dw}$ ), and $\mathrm{CPH}(142.7 \mathrm{ng}$ per $\mathrm{g} \mathrm{dw})$ was ent-9(RS)-12-epi-ST- $\Delta^{10}-13$ PhytoF, which was already detected in melon leaves ${ }^{24}$ and in brown rice bran (4.6 $\mathrm{ng}$ per $\mathrm{g} \mathrm{dw}$ ). ${ }^{30}$ The less predominant PhytoF in CP, CH, and CPH was ent-16(RS)-9-epi-ST- $\Delta^{14}-10$ PhytoF, present at $163.2,62.8$, and $43.5 \mathrm{ng}$ per $\mathrm{g}$ dw, respectively. This compound was identified in different rice cultivars and the highest concentrations detected were $1.25,4.21$, and $12.88 \mathrm{ng}$ per $\mathrm{g} \mathrm{dw}$ for white flour, brown flour, and bran, respectively. ${ }^{30}$

The highest concentration of PhytoFs was detected in CP, followed by $\mathrm{CPH}$ and $\mathrm{CH}$. Interestingly, the same order in the concentration of ALA was observed in our investigated samples (160.7, 82.8, and 52.1 $\mathrm{mg}$ per $\mathrm{g} \mathrm{dw}$ ) in $\mathrm{CP}, \mathrm{CPH}$, and $\mathrm{CH}$, respectively (Fig. 3). It would be interesting to quantify these compounds from freshly harvested samples of $\mathrm{CP}, \mathrm{CH}$, and $\mathrm{CPH}$, to determine the influence of primary and/or secondary processing on the content of ALA, PhytoFs, and PhytoFs, in order to demonstrate whether a correlation exists. Some authors working on nuts, seeds, and animal tissues show that the PhytoF concentration was not ALA-dependent, but probably oxidative stress condition-dependent. ${ }^{33}$ Anyhow, the quantification of PhytoPs and PhytoFs could provide a unique sensitive indication of oxidant injury (crop conditions and postharvest factors).

\section{Conclusions}

The coffee and cocoa co- and by-products present a major problem for waste disposal, leading to disease propagation or environmental issues, both in the producing countries and in the processing countries. To the best of our knowledge, this is the first time that a qualitative and quantitative profile of PhytoPs and PhytoFs in $\mathrm{CP}, \mathrm{CH}$, and $\mathrm{CPH}$ has been determined. The concentrations of these compounds retrieved from coffee and cocoa by- and co-products suggest that these residues are a valuable source of PhytoPs and PhytoFs. Thus, this research contributed to complete the actual portfolio of interesting biomolecules derived from coffee and cocoa by- and coproducts. Further research is needed to investigate how different edaphoclimatic and processing conditions, as well as the species, influence the qualitative and quantitative profile of PhytoPs and PhytoFs in coffee and cocoa co- and byproducts. The use of such residues as a source of bioactive compounds could provide an economical alternative to the farmers and smallholders in the producing countries. Indeed, taking into account the wide range of biological activities shown here (anti-inflammatory activities, apoptosis, immune function regulation, and neuroprotection) and those which still remain to be elucidated, there is scope for the implementation of such compounds. In this context, PhytoP and PhytoF rich extracts could be obtained from these residues to be used in the functional food industry for enriching food or as nutritional supplements.

Although additional studies are necessary, this work opens new insights and prospects, not only to add value to these agro-wastes but also to pave the way towards the interest of enlarging this study to green coffee bean and cocoa nibs and their derived products.

\section{Abbreviations}

$\begin{array}{ll}\text { ACN } & \text { Acetonitrile } \\ \text { ALA } & \alpha \text {-Linolenic acid (C18:3 n-3) } \\ \text { BHT } & \text { Butylated hydroxytoluene } \\ \text { CH } & \text { Cocoa husk } \\ \text { CP } & \text { Coffee pulp } \\ \text { CPH } & \text { Cocoa pod husk } \\ \text { dw } & \text { Dry weight } \\ \text { ESI } & \text { Electrospray } \\ \text { EY } & \text { Extraction yield } \\ \text { FAMEs } & \text { Fatty acid methyl esters } \\ \text { GC } & \text { Gas chromatography } \\ \text { HPLC } & \text { High-performance liquid chromatography } \\ \text { IS } & \text { Internal standards } \\ \text { IsoFs } & \text { Isofurans } \\ \text { IsoPs } & \text { Isoprostanes } \\ \text { LC-MS/MS } & \text { Liquid chromatography tandem mass spectrometry } \\ \text { LOD } & \text { Limit of detection } \\ \text { LOQ } & \text { Limit of quantification } \\ \text { ME } & \text { Matrix effect } \\ \text { MeOH } & \text { Methanol } \\ \text { MRM } & \text { Multiple reaction monitoring } \\ \text { PhytoPs } & \text { Phytoprostanes } \\ \text { PhytoFs } & \text { Phytofurans } \\ \text { PUFAs } & \text { Polyunsaturated fatty acids } \\ \text { QTRAP } & \text { Triple-quadrupole mass spectrometer combined } \\ \text { SPE } & \text { with a linear ion trap } \\ & \text { Solid phase extraction } \\ & \end{array}$

\section{Conflicts of interest}

There are no conflicts of interest to declare. 


\section{Acknowledgements}

This work was supported by the Consejo Nacional de Ciencia y Tecnología (CONACyT, Mexico) (grant number 405131).

\section{References}

1 S. I. Mussatto, E. M. S. Machado, S. Martins and J. A. Teixeira, Production, Composition, and Application of Coffee and Its Industrial Residues, Food Bioprocess Technol., 2011, 4, 661-672.

2 E. Lecumberri, R. Mateos, M. Izquierdo-Pulido, P. Ruprez, L. Goya and L. Bravo, Dietary fibre composition, antioxidant capacity and physico-chemical properties of a fibrerich product from cocoa (Theobroma cacao L.), Food Chem., 2007, 104(3), 948-954.

3 Food and Agriculture Organization of the United Nations, Crop statistics, FAOSTAT, 2017.

4 S. Roussos, M. De Los Angeles Aquiahuatl, M. D. R. TrejoHernández, I. Gaime Perraud, E. Favela, M. Ramakrishna, et al., Biotechnological management of coffee pulp- isolation, screening, characterization, selection of caffeinedegrading fungi and natural microflora present in coffee pulp and husk, Appl. Microbiol. Biotechnol., 1995, 42, 756-762.

5 M. A. Ramirez-Coronel, N. Marnet, V. S. Kolli, S. Roussos, S. Guyot and C. Augur, Characterization and Estimation of Proanthocyanidins and Other Phenolics in Coffee Pulp (Coffea arabica) by Thiolysis-High-Performance Liquid Chromatography, J. Agric. Food Chem., 2004, 52, 1344-1349.

6 E. Sangronis, M. J. Soto, Y. Valero and I. Buscema, Cascarilla de cacao venezolano como materia prima de infusiones, Arch. Latinoam. Nutr., 2014, 64(2), 123-130.

7 O. Adi-dako, K. Ofori-Kwakye, S. Frimpong Manso, M. El Boakye-Gyasi, C. Sasu and M. Pobee, Physicochemical and antimicrobial properties of cocoa pod husk pectin intended as a versatile pharmaceutical excipient and nutraceutical, J. Pharm., 2016, 2016, 1-12.

8 D. C. G. Okiyama, S. L. B. Navarro and C. E. C. Rodrigues, Cocoa shell and its compounds: Applications in the food industry, in Trends in Food Science \& Technology, Elsevier Ltd, 2017, pp. 103-112.

9 L. C. Vriesmann, R. Amboli, C. Petkowicz and C. L. De Oliveira Petkowicz, Cacao pod husks (Theobroma cacao L.): Composition and hot-water-soluble pectins, Ind. Crops Prod., 2011, 34(1), 1173-1181.

10 SIAP. Anuario Estadístico de la Producción Agrícola. siap. gob.mx, 2017.

11 J. E. Braham, R. Bressani, A. Panama, C. Rica, E. Salvador and H. Guatemala, et al., Coffee pulp: Composition, Technology and Utilization, ed. J. E. Braham and R. Bressani, Panama, 1979, p. 95.

12 B. M. Yapo and K. L. Koffi, Extraction and Characterization of Gelling and Emulsifying Pectin Fractions from Cacao Pod Husk, J. Food Nutr. Res., 2013, 1(4), 46-51.
13 P. Esquivel and V. M. Jiménez, Functional properties of coffee and coffee by-products, Food Res. Int., 2012, 46(2), 488-495.

14 M. A. Arellano-González, M. A. Ramirez-Coronel, M. T. Torres-Mancera, G. G. Pérez-Morales and G. SaucedoCastañeda, Antioxidant Activity of Fermented and Nonfermented Coffee (Coffea arabica) Pulp Extracts, Food Technol. Biotechnol., 2011, 49(3), 347-378.

15 M. Matsumoto, M. Tsuji, J. Okuda, H. Sasaki, K. Nakano, K. Osawa, et al., Inhibitory effects of cacao bean husk extract on plaque formation in vitro and in vivo, Eur. J. Oral Sci., 2004, 112, 249-252.

16 R. Imbusch and M. J. Mueller, Formation of isoprostane $\mathrm{F}(2)$ )like compounds (phytoprostanes $\mathrm{F}(1)$ ) from alphalinolenic acid in plants, Free Radicals Biol. Med., 2000, 28(5), 720-726.

17 A.M. Carrasco-Del Amor, E. Aguayo, J. Collado-González, A. Guy, J. M. Galano, T. Durand, et al. Impact of processing conditions on the phytoprostanes profile of three types of nut kernels, Free Radical Res., 2017, 51(2), 141-147.

18 C. Cuyamendous, K. S. Leung, T. Durand, J. C.-Y. Lee, C. Oger and J.-M. Galano, Synthesis and discovery of phytofurans: metabolites of $\alpha$-linolenic acid peroxidation, Chem. Commun., 2015, 51(86), 15696-15699.

19 L. Minghetti, R. Salvi, M. L. Salvatori, M. A. Ajmone-Cat, C. De Nuccio, S. Visentin, et al. Nonenzymatic oxygenated metabolites of $\alpha$-linolenic acid B1- and L1-phytoprostanes protect immature neurons from oxidant injury and promote differentiation of oligodendrocyte progenitors through PPAR- $\gamma$ activation, Free Radicals Biol. Med., 2014, 73, 41-50.

20 M. J. Mueller, Archetype signals in plants: The phytoprostanes, Curr. Opin. Plant Biol., 2004, 7(4), 441-448.

21 T. Durand, V. Bultel-Poncé, A. Guy, S. El Fangour, J. C. Rossi and J. M. Galano, Isoprostanes and phytoprostanes: Bioactive lipids, Biochimie, 2011, 93, 52-60.

22 D. León-Perez, S. Medina, J. Londoño-Londoño, M. CanoLamadrid, Á. Carbonell-Barrachina, T. Durand, et al., Comparative study of different cocoa (Theobroma cacao L.) clones in terms of their phytoprostanes and phytofurans contents, Food Chem., 2019, 280, 231-239.

23 S. Medina, Á. Gil-Izquierdo, T. Durand, F. Ferreres and R. Domínguez-Perles, Structural/Functional Matches and Divergences of Phytoprostanes and Phytofurans with Bioactive Human Oxylipins, Antioxidants, 2018, 7(165), 1-19.

24 M. E. Yonny, A. Rodríguez Torresi, C. Cuyamendous, G. Réversat, C. Oger, J. M. Galano, et al. Thermal Stress in Melon Plants: Phytoprostanes and Phytofurans as Oxidative Stress Biomarkers and the Effect of Antioxidant Supplementation, J. Agric. Food Chem., 2016, 64(44), 82968304.

25 J. Collado-González, S. Medina, T. Durand, A. Guy, J. Galano, A. Torrecillas, et al. New UHPLC - QqQ-MS/MS method for quantitative and qualitative determination of free phytoprostanes in foodstuffs of commercial olive and sunflower oils, Food Chem., 2015, 178, 212-220. 
26 B. K. Matuszewski, M. L. Constanzer and C. M. Chavez-Eng, Strategies for the assessment of matrix effect in quantitative bioanalytical methods based on HPLC-MS/MS, Anal. Chem., 2003, 75(13), 3019-3030.

27 J. Collado-González, A. Moriana, I. Giron, M. Corell, S. Medina, T. Durand, et al. The phytoprostane content in green table olives is influenced by Spanish-style processing and regulated deficit irrigation, LWT-Food Sci. Technol., 2015, 64, 997-1003.

28 Instituto Nacional para el Federalismo y Desarrollo municipal. Enciclopedias de los municipios y delegaciiones en México. INAFED, 2017.

29 A. K. Chapagain and A. Y. Hoekstra, The water footprint of coffee and tea consumption in the Netherlands, Ecol. Econ., 2007, 64(1), 109-118.

30 M. Pinciroli, R. Domínguez-Perles, A. Abellán, A. Guy, T. Durand, C. Oger, et al., Comparative Study of the Phytoprostane and Phytofuran Content of indica and japonica Rice (Oryza sativa L.) Flours, J. Agric. Food Chem., 2017, 65, 8938-8947.

31 K. Karg, V. M. Dirsch, A. M. Vollmar, J. L. Cracowski, F. Laporte and M. J. Mueller, Biologically active oxidized lipids (phytoprostanes) in the plant diet and parenteral lipid nutrition, Free Radical Res., 2007, 41(1), 25-37.

32 C. Loeffler, S. Berger, A. Guy, T. Durand, G. Bringmann, M. Dreyer, et al., B1-Phytoprostanes Trigger Plant Defense and Detoxification Responses, Plant Physiol., 2005, 137, 328-340.

33 A. M. Carrasco-Del Amor, J. Collado-Gonzalez, E. Aguayo, A. Guy, J. M. Galano, T. Durand, et al., Phytoprostanes in almonds: Identification, quantification, and impact of cultivar and type of cultivation, RSC Adv., 2015, 5, 51233-51241.

34 J. Marhuenda, S. Medina, A. Díaz-Castro, P. MartínezHernández, S. Arina, P. Zafrilla, et al. Dependency of Phytoprostane Fingerprints of Must and Wine on
Viticulture and Enological Processes, J. Agric. Food Chem., 2015, 63(41), 9022-9028.

35 S. Medina, J. Collado-González, F. Ferreres, J. Londoño-Londoño, C. Jiménez-Cartagena, A. Guy, et al., Quantification of phytoprostanes -bioactive oxylipins- and phenolic compounds of Passiflora edulis Sims shell using UHPLC-QqQ-MS/MS and LC-IT-DAD-MS/MS, Food Chem., 2017, 229, 1-8.

36 J. Collado-González, A. Moriana, I. F. Girón, M. Corell, A. Galindo and S. Medina, et al., Effect of Deficit Irrigation and Elaboration Process of Spanish-Style Green Table Olives on Phytoprostanes Content in Manzanilla de Sevilla Olive Flesh, in XII Portuguese-Spanish Symposium on Plant Water Relations, 2014, pp. 16-20.

37 M. C. García-García, M. del Río Celestino, Á. Gil-Izquierdo, C. Egea-Gilabert, J. M. Galano, T. Durand, et al. The Value of Legume Foods as a Dietary Source of Phytoprostanes and Phytofurans Is Dependent on Species, Variety, and Growing Conditions, Eur. J. Lipid Sci. Technol., 2019, 1800484(121), 1-12.

38 C. Cuyamendous, A. de la Torre, Y. Y. Lee, K. S. Leung, A. Guy, V. Bultel-Poncé, et al. The novelty of phytofurans, isofurans, dihomo-isofurans and neurofurans: Discovery, synthesis and potential application, Biochimie, 2016, 130, 49-62.

39 C. Vigor, G. Reversat, A. Rocher, C. Oger, J. M. Galano, J. Vercauteren, et al. Isoprostanoids quantitative profiling of marine red and brown macroalgae, Food Chem., 2018, 268(January), 452-462.

40 L. S. Oliveira and A. S. Franca, An Overview of the Potential Uses for Coffee Husks, in Coffee in Health and Disease Prevention, ed. V.R Preedy, Academic Press, 2015, pp. 283-291.

41 Association of Official Analytical Chemists, AOAC, Washington, DC, 18th edn, 2005.

42 AFNOR (Association Française de Normalisation), Corps gras, oléagineux, produits derivés, 3rd edn, 1984. 